\title{
Job Satisfaction among Academicians at Business Colleges Operating in Kuwait
}

\author{
Abdullah AL-Mutairi ${ }^{1}$, Kamal Naser $^{2} \&$ Meshref Al-Enezi ${ }^{3}$ \\ ${ }^{1}$ Gulf University for Science and Technology, Kuwait \\ ${ }^{2}$ Financial Advisor, Kuwait Fund, Kuwait \\ ${ }^{3}$ Arab Open University- Kuwait Branch, Kuwait \\ Correspondence: Abdullah AL-Mutairi. E-mail: mutairi.a@gust.edu.kw
}

Received: September 24, 2017

doi:10.5539/ass.v13n12p9

\author{
Accepted: October 13, 2017 \\ Online Published: November 28, 2017 \\ URL: https://doi.org/10.5539/ass.v13n12p9
}

\begin{abstract}
The purpose of this study is to examine the overall level of job satisfaction of the academicians who work for business colleges operating in Kuwait and to identify whether demographics affect the level of job satisfaction.

During the period between December 2016 and March 2017, a short-form Minnesota Satisfaction Questionnaire (MSQ) was distributed to 240 academicians working for eight Kuwaiti business colleges including: Arab Open University (AOU), American University of Kuwait (AUK), Gulf University for Science and Technology (GUST), Australian College of Kuwait (ACK), Public Authority for Applied Education and Training (PAAET), Box Hill College (BHC), Kuwait University (KU) and the American University in Middle East (AUME). A total of 141questionnaires were returned; resulting in $59 \%$ usable response rate.

The study showed that academicians in business colleges operating in Kuwait are relatively job satisfied and their characteristics impact the level of their satisfaction. However, the most significant characteristics that affect the level of their job satisfaction were income, nationality and gender.

The outcome of this study can be used by policy makers to develop recruitment and promotion policies. This would assist in achieving high levels of job satisfaction and will have positive effect on the academic process and the higher education system at large. This is the first study that used MSQ to explore job satisfaction among academicians who work for eight business colleges in Kuwait. The outcome of the study is expected to help decision makers in enhancing the level of the academicians' job satisfaction.
\end{abstract}

Keywords: Job satisfaction, Academic staff, Minnesota Satisfaction Questionnaire, Factors affecting job satisfaction, Business colleges, university, Kuwait

\section{Introduction}

Job satisfaction is an important issue that organizations aspire for their employees. It reflects the extent to which an employee is pleased with his/ her job. The level of satisfaction is influenced by employee's perception and the feelings about the job. The level of employee satisfaction can be also influenced by employee's characteristics and the job nature. As far as university academic staff is concerned, empirical research pointed to several factors that influence their level of job satisfaction including the work itself, department heads' behavior, pay and promotion. A negative relationship is detected between academic employees' job satisfaction and job stress (Shamra \& Manani, 2012). The findings of previous empirical research would be inapplicable to the academic staff of business colleges operating in Kuwait due to the high education environment in Kuwait. The higher education system in Kuwait has the liberty to adopt different education system. Although the only state university (Kuwait University) and the college (Public Authority for Applied Education and Training) adopt the American system of education with some variations to accommodate the Kuwaiti culture and Arabic language, the remaining private universities adopt different education systems including the American, British and Australian systems of education. Consequently, work environment in terms of the curriculum, teaching methods and assessment methods, staff recruitment, compensation and promotion policies are not identical in these universities. Hence, the level of academic staff satisfaction is expected to vary among these universities. It is, therefore, important to study academic staff satisfaction in these universities. The importance of this study stems from the fact that academic staff satisfaction or otherwise is likely to influence the lecturer performance and this in return has a major effect on the outcome of the education process and the objective of the higher education system at large. Exploring job satisfaction among academicians identifies areas that need to be developed and this would assist policymakers in formulating their academic staff recruitment, retention, compensation and promotion policies to ensure minimum absenteeism, turnover and increase their productivity. This would have a positive effect on the business higher education process and assist in achieving the objective of the country's higher education system. The rest of this paper is organized as follow. Related literature and previous studies are reviewed in the next section. Research method adopted for this study is described in section three. While the findings of the study 
are presented in section four, the conclusion is offered in final section.

\section{Related literature and previous studies}

Different definitions have been used in the literature to describe job satisfaction. According to Webster's Dictionary (1986), job satisfaction refers to how well a job serves as a source of enjoyment. Robbins et al. (2003) defined job satisfaction as an individual's general attitude toward his or her job. Rothman and Cooper (2008) defined job satisfaction as a pleasurable state ensuing from the appraisal of one's job. Steyn and Van (1999) considered job satisfaction as strong predictor for an individual to decide to stay or leave the organization. Although there is no universal identical definition for job satisfaction, job satisfaction is the reaction to a job that results from comparison between actual outcomes with those that are desired (Oshagbemi, 2003). Shamra and Manani, 2012 believe that job satisfaction has a significant effect on absenteeism, turnover and job performance. Mehmood et al. (2012) also revealed that job dissatisfaction is among the best predictors of staff turnover.

The literature pointed to three major theoretical frameworks of job satisfaction. The first one is content theory. It assumes job satisfaction takes place when individual's need for growth and self-actualization are come together by an individual's job (Saif et al. 2012). The second one is process theory that attempts to explain job satisfaction by looking at how well the job meets one's expectations and values. It proposes that individuals select their behavior in order to reach their needs. In other words, process theories identify relationships among variables that make up motivation (Teck-Hong \& Waheed, 2011). The third one is situational theory proposes that job satisfaction is a consequence of how well individual's personal characteristics interact with the organizational characteristics. The situational theory depends upon two factors: situational characteristics and situational occurrences. Situational characteristics are things well known by the employee before accepting the job such as pay; while the situational occurrences are things that occur after taking a job. They might be positive or negative occurrences. Therefore, job satisfaction is a product of both situational factors and situational occurrences.

Based on the above theories, several studies have developed to identify factors behind job satisfaction among academic staff. They were undertaken in various places (see for example, UK: Oshagbemi, 1996, 2000, 2003, Ward and Sloane 2000, Stevens 2005; Canada: Leckie and Brett 1997; Turkey: Kusku 2003, Bayram et al. 2010, Toker 2011, Saygi et al. 2011; Uganda: Sseganga 2003, Sseganga and Garrett 2005, Malaysia: Santhapparaj and Alam 2005, Noordin and Jusoff 2009, Hashim and Mahmood 2011, Mustapha 2013, Ahmad and Abdurahman 2015; South Africa: Schulze 2006, Basak, 2014; USA: Bendern and Heywoodn 2006, Baldwin 2009, Leysen and Boydston 2009; Zimbabwe: Chimanikire et al. 2007; Iran: Zarafshani and Alibaygi 2008; Cyprus: Eyupoglu and Saner 2009; Pakistan: Saba 2011; Malik 2011, Khalid et al. 2012, Mehmood et al. 2012, Sohail and Delin 2013, Syed and Ahmedani 2013; India. Shamra and Manani 2012; Jordan: Abushaira 2012; Vietnam: Wang et al. 2014; Shin and Jung 2014 ${ }^{1}$ ). The following section will review in brief these studies.

Oshagbemi (1996, 2003) examined job satisfaction among academicians who work for 23 British universities. He found that academicians are satisfied with teaching, research, and interactions with colleagues. He also found that academicians are only moderately satisfied with department heads' behavior and physical working conditions. He observed that academicians are dissatisfied with pay, promotion, and performance of administrative duties. Oshagbemi concluded that the rank of an individual and the length of service he/she has worked within higher education are significant predictors of the level of the individual's overall job satisfaction. Another study performed by Ward and Sloane (2000) who measured job satisfaction of 900 academicians from five traditional Scottish Universities. They found women generally express themselves as more satisfied with their jobs than men. They also found that levels of overall job satisfaction among academicians are high. Ward and Sloane observed that job satisfaction generally declines with level of education. Stevens (2005) measured job satisfaction of English academicians in UK. He found insignificant difference in job satisfaction of male and female academicians. He also found that professors are on the whole happier in their jobs than lower grades. Stevens observed that the impact of experience on quits declines for the first thirteen to seventeen years and remains negative until experience hits the mid to late twenties.

Leckie and Brett (1997) examined job satisfaction of Canadian university librarians. They found that academic librarians are satisfied with the traditional elements of librarianship itself a strong emphasis on service, independence, creativity, using one's judgment, and participation in professional activities. They also found academic librarians are more satisfied with the promotion and tenure process and with support for doing research. However, Leckie and Brett observed that academic librarians are insignificantly satisfied with their assigned duties, workloads and relationships with users and colleagues.

Kusku (2003) explored differences in satisfaction dimensions between academic and administrative employees in Turkey. She noticed certain differences in factors such as "colleague relations satisfaction", "colleague competition level satisfaction", "other work group satisfaction", "professional satisfaction", "work environment satisfaction", and "salary satisfaction". Bayram et al. (2010) examined the degree of burnout and vigor experienced in an academic environment and the relation of these factors to job satisfaction in Turkey. They found the highest scores for burnout were those of the academicians in the health sciences department. They also observed 22 percent of the variance in job

\footnotetext{
1 This study explored academics job satisfaction and job stress across 19 countries including Argentina, Australia, Brazil, Canada, China, Finland, Germany, Hong Kong, Japan, Italy, Korea, Malaysia, , Mexico, Netherlands, Norway, Portugal, South Africa, UK, USA.
} 
satisfaction is explained by burnout and intrinsic job satisfaction was more important than burnout. Bayram et al. concluded that female academicians are more vulnerable to developing burnout than males. Another study conducted by Toker (2011) who used MSQ to examine the levels of job satisfaction among academicians in the universities of Turkey. He found social status ranked as the highest and compensation as the lowest of the examined items. He also found professors reported a higher level of job satisfaction as compared to instructor and research assistants. Toker concluded that marital status and gender are not significantly related to job satisfaction. An additional study conducted in Turkey by Saygi et al. (2011) who demonstrated that the most important factor in job satisfaction is coworkers, working as a team and sharing also rated as important. They observed insignificant differences in factors rating according to gender.

Sseganga (2003) examined factors that contribute to academic satisfaction and dissatisfaction in higher education in two Ugandan universities. He found that the factors most prevalent in the prediction of dons' satisfaction relate to co-worker behavior, supervision and intrinsic facets of teaching. He also found that extrinsic factors with respect to remuneration, governance, research, promotion, and working environment are factors that create academic dissatisfaction. Sseganga presented no evidence to support gender influence on dons' job satisfaction. Another study undertaken by Sseganga and Garrett (2005) showed academicians rated satisfaction is derived from intrinsic factors of teaching like interest shown by students in courses taught and autonomy of content taught suggesting that Ugandan academicians are sociable beings and value their friendly interactions. Sseganga and Garrett added that academicians are not satisfied with salary, research grants and library facilities.

Santhapparaj and Alam (2005) examined the relationship between pay, promotion, fringe benefits, working condition, research support, teaching support, gender and job satisfaction of academic staff in private universities in Malaysia. They found pay, promotion, working condition and support of research have positive and significant effect on job satisfaction. They also found female staff to be more satisfied than their counterpart. Another study conducted by Noordin and Jusoff (2009) to examine job satisfaction of academic staff of a public university in Malaysia. They found overall academic staff of the university to be moderately satisfied. They also found the current status, marital status, age and salary to have significant impact on the respondents' level of job satisfaction. Noordin and Jusoff provided evidence that the male respondents have a significantly higher level of general satisfaction than their female counterparts. Hashim and Mahmood (2011) investigated job satisfaction of academic staff from both public and private universities in Malaysia and found that they are satisfied with the overall job contents and contexts of their job. They observed that academic staff of both universities has ranked "salary" as being "least satisfied". Hashim and Mahmood concluded that there are other variables such as consultancy work, variety of jobs and governance also play important role in increasing job satisfaction.

Another study performed by Mustapha (2013) who examined financial reward effect on job satisfaction among lecturers in four public universities. He found a positive relationship between financial reward and job satisfaction. Mustapha recommended that organization should consider financial reward as one of the factors in promoting job satisfaction among employees. Recently, Ahmad and Abdurahman (2015) examined the level of job satisfaction among lecturers at one of the public universities in Malaysia. They found most participants have moderate level of job satisfaction and lecturers are satisfied with the work environment. Another recent study by Mehrad et al. (2015) examined the role of job satisfaction among university academic staff. They found the existence of job satisfaction as basic human needs can develop and support academic staff's performances and conduct their organizational behavior in an accurate manner.

Schulze (2006) used a questionnaire survey to examine job satisfaction in higher education in South Africa and found academicians are in general satisfied. He also found that job satisfaction has the highest correlation with physical conditions and support, research and thereafter compensation and other benefits offered by the university. He observed factors that caused dissatisfaction include government interference in teaching; poor quality of students' work and lack of time to do research. Schulze concluded that improvement in job satisfaction among academicians could be achieved by increasing availability of research assistants, research support and organizing workshops to improve academicians' research skills. Another study conducted by Basak (2014) found satisfaction factors are more than dissatisfaction factors and university academics are more satisfied than dissatisfied.

Bender and Heywoodn (2006) surveyed determinants of job satisfaction of PhD-level scientists in the United States for both academic and nonacademic sectors. They found that while academic scientists with tenure have substantially greater job satisfaction than nonacademic scientists, academic scientists without tenure have the similar levels of job satisfaction as non-academic scientists. They also found female scientists have lower job satisfaction than males in the academic sector but higher level of job satisfaction in the non-academic sector. Bendern and Heywoodn observed that women, who may be more likely to demand flexible jobs, would be more satisfied than men. They further noticed that job satisfaction is directly related to income within the sector, while comparison across sectors does not affect job satisfaction. Another study conducted by Leysen and Boydston (2009) who measured job satisfaction among academic cataloger librarians and found the majority of academic cataloger librarians are satisfied with their current job and they would make the same career choice again. They also found cataloger librarians are satisfied with the benefits package, relationships with coworkers, and opportunities to learn new skills. Leysen and Boydston observed that catalogers wanted to be treated fairly, be asked about matters directly linked to their job and have their thoughts appreciated and 
considered.

Another study conducted by Baldwin (2009) who used a questionnaire survey to examine job satisfaction of men and women administrators in higher education in four-year public institutions in Alabama. He found administrators are satisfied in terms of present job duties, pay, opportunities for promotion, and supervision. He also found administrators expressed a level of dissatisfaction with the people with whom they work and their job in general. Baldwin observed male administrators as being more satisfied with their work climate than the female administrators.

Chimanikire et al. (2007) examined factors affecting job satisfaction among academic professionals in tertiary institutions of Zimbabwe. They found the majority of the academic staff are not satisfied with their jobs. The reasons for dissatisfaction were high volume of work and insufficient salaries. Chimanikire et al. concluded that there is a need to introduce incentive package that addresses the concerns of academic staff on issues related to job satisfaction.

Zarafshani and Alibaygi (2008) used modified version of the MSQ to examine job satisfaction among academic staff of Razi University in Iran. They found faculties are satisfied with their jobs in general. However, they are more satisfied from intrinsic factors such as social service, activity, and ability utilization and least satisfied from the extrinsic job satisfaction dimensions such as salary, university policy and job security. Zarafshani and Alibaygi concluded that as an attempt to motivate faculties to stay, they should realize that their effort is appreciated first then they should be provided with superior monetary compensation and improved job security.

Eyupoglu and Saner (2009) used a short-form MSQ to examine levels of job satisfaction among academicians in North Cyprus. They found academicians enjoy a moderate level of overall job satisfaction. They also found university policies and practices and compensation are clearly responsible for dissatisfaction. Eyupoglu and Saner provided evidence that moral values, social service, creativity and achievement are responsible for satisfaction.

Saba (2011) examined job satisfaction level of academic staff in Pakistan. He found academic staff of the colleges are more satisfied with the work itself, pay, working conditions, job security and coworkers and less satisfied with promotion opportunities. He also found teachers are satisfied with their coworkers because they cooperate with them and also provide them sufficient supports whenever they need them. Saba provided evidence to support that young teachers find the salary level in public institutions very attractive and find it very reasonable when compare it with their qualification. Malik (2011) added that the faculty members are generally satisfied with their jobs and male faculty members are less satisfied than female faculty members. He also observed that "work itself" is the most motivating aspect for faculty and "working conditions" is the least motivating aspect. Malik concluded that demographic characteristics such as age, years of experience, academic rank, degree are negligibly related to overall job satisfaction. Another study conducted by Khalid et al. (2012) examined the relationship between various facets of job satisfaction among university academicians in Pakistan. They found pay differential exists between private and public universities in Pakistan and observed that academicians in private universities are more satisfied with their pay, supervision, and promotional opportunities than academicians in public university. Khalid et al. concluded that academicians in public universities are found more satisfied with co-worker's behavior and job security.

Another study performed by Mehmood et al. (2012) who noticed a relationship between employees job satisfaction and their salaries and benefits, working conditions, and autonomy. They also noticed work environment is a predominant factor that effects the level of satisfaction. Mehmood et al. concluded that the organizational setup improve the satisfaction level of employee and increase in performance. Sohail and Delin (2013) added that Job security and co- worker relation have major impact on employees' satisfaction. Syed and Ahmedani (2013) used a questionnaire survey to compare job satisfaction among faculty members of University of Sindh with Shah Abdul Latif University Khairpur Mirs. They found that job satisfaction is determined by a summation of many attitudes possessed by an employee concerning the job and other contextual factors. They observed that the teaching staff of the University of Sindh-Jamshoro is highly satisfied with their job when compared to the teaching staff in Shah Abdul Latif University Khairpur Mirs.

Shamra and Manani (2012) tested factors affecting job satisfaction among head teachers in India. They found that the main factors are work conditions, supervision and relationships. They observed that work itself, and advancement explained 60 percent of the variance among faculty members overall level of job satisfaction. Shamra and Manani concluded that job satisfaction is negatively related to job stress.

Abushaira (2012) looked into job satisfaction among teachers in Jordan and found their level of job satisfaction was moderate. He also found significant differences in the respondents' level of job satisfaction due to age favoring younger teachers. He could not find a relationship between job satisfaction and gender. Abushaira suggested the necessity of providing an appropriate work atmosphere to encourage the teachers who work with the multi-disabled students.

Wang et al. (2014) examined factors that are closely associated with job satisfaction of employees working at job consulting center in Vietnam. They found factors such as administration, working condition and staff interaction have the strongest impact on the overall satisfaction. They also observed that the organization operates effectively only if teacher and staff can self-recognize themselves as important resources that have scarified all their life for the development of working place. Wang et al. concluded that the compensation is a central component of effective policy-making. 
In a comprehensive study of academicians' job satisfaction and job stress across 19 countries, Shin and Jung (2014) employed regression analysis to assess whether new public management affects job satisfaction or job stress. They noticed that while European countries are in the high satisfaction group, countries driven by strong market are in high stress group. In other words, while market oriented managerial reforms appeared to be the main source of academic stress, academicians' high social reputation and their autonomy are the main source of job satisfaction. The result of the regression analysis undertaken by Shin and Jung (2014) revealed that performance-based management is the main source of academic job stress. They also reported that while high satisfaction is associated with higher education systems, it also has high stress groups.

As far as the GCC region is concerned, a limited number of studies were undertaken to examine factors affect academic staff job satisfaction (see for example, Kuwait: Bader, 1983; Oman: Zayed, 2008; Saudi Arabia: Al-Rubaish et al., 2009). The following section reviews in brief these studies.

Bader (1983) adopted a questionnaire survey to examine job satisfaction among staff and administrators in Kuwait University. He found faculty members and administrators are highly satisfied in relation to their supervisor and co-workers and fairly satisfied with subordinates work planning, job position accomplishment and working hours. He also observed that academicians and administrators are less satisfied in relation to promotion opportunities, decision-making and advancement and are dissatisfied with respect to other fringes and benefits such as housing. Bader found insignificant relationship between job satisfaction and material status, age and gender.

Zayed (2008) investigated the relationship between job satisfaction and variables such as gender, qualification, marital status, and years of experience of Omani physical educators working at governmental schools. He found the majority of participants are moderately satisfied. He provided evidence that the most important factor affecting job satisfaction is the finance income, whereas the majority of participants are either dissatisfied or slightly satisfied with their salaries. Zayed concluded that the educators who have less than five years of service are more satisfied than their counterparts who have more than five years of service and married physical educators are less job satisfied than singles physical educators.

Al-Rubaish et al. (2009) examined the state of job satisfaction among the academic staff of King Faisal University. They found most academic staff are fairly satisfied with their jobs and job satisfaction varied widely across job domains and demographic characteristics. They also found that all categories of staff are most dissatisfied with their salaries and females were significantly less satisfied than their male counterparts. Al-Rubaish et al. concluded that the overall job satisfaction rate among university academic staff in Saudi Arabia is fair in comparison with some studies from other countries.

It is evident from brief review of the literature that little research has been undertaken in the area of job satisfaction among university academic staff in the GCC countries. This suggests the need for empirical testing in different environmental contexts of country and time to enhance understanding of job satisfaction among academicians at business colleges operating in Kuwait. This provides clear justification for this study.

\section{Study Methodology}

\subsection{Research instrument}

The current study is based on a short-form Minnesota Satisfaction Questionnaire (MSQ) to measure job satisfaction of the academicians (Weiss et al., 1967) ${ }^{2}$. The questionnaire consisted of twenty facets and each facet represented one satisfaction item. It is one of the most commonly used tool in measuring job satisfaction (Eyupoglu and Saner, 2009) and its validity and reliability have been confirmed for more than 45 years of application. It has been employed to measure job satisfaction of academicians in several places and it has the adaptability advantage. During the period between December 2016 and March 2017, a translated version of the questionnaire was distributed to 240 academicians working in eight Kuwaiti business colleges. 141 questionnaires were returned; resulting in 59\% usable response rate. A summary of their response is presented in table (1).

Table 1. Respondents response rate

\begin{tabular}{cccc}
\hline Academic Institution & $\begin{array}{c}\text { Number of questionnaires } \\
\text { distributed }\end{array}$ & $\begin{array}{c}\text { Number of questionnaires } \\
\text { returned }\end{array}$ & $\begin{array}{c}\text { Response rate } \\
(\%)\end{array}$ \\
\hline Arab Open University & 30 & 17 & 57 \\
American University of Kuwait & 30 & 17 & 57 \\
Gulf University for Science and Technology & 30 & 16 & 53 \\
Australian College of Kuwait & 30 & 17 & 57 \\
Public Authority for Education and Training & 30 & 21 & 70 \\
Box Hill College & 30 & 25 & 83 \\
Kuwait University & 30 & 21 & 70 \\
American University of the Middle East & $\underline{30}$ & $\underline{\underline{240}}$ & $\underline{141}$ \\
Total & & $\underline{\underline{59}}$ \\
\hline
\end{tabular}

\footnotetext{
${ }^{2}$ The long-form MSQ consists of 100 items, which make up 20 scales/facets of the job.
} 
The questionnaires were then entered in an SPSS file for analysis. Cronbach's Alpha test was used to measure the internal consistency of the collected data. Descriptive statistics have been utilized to shed some light on the respondents and their response to various items of job satisfaction. Backward regression analysis was performed to identify the most significant academicians' characteristics that determine the level of job satisfaction. The estimated regression model is summarized as follows.

$$
\begin{gathered}
\mathrm{JSAT}=\beta_{0}+\beta_{1} \mathrm{NAT}+\beta_{2} \mathrm{UNIV}+\beta_{3} \mathrm{GEN}+\beta_{4} \mathrm{MARS}+\beta_{5} \mathrm{ACCR}+ \\
\beta_{6} \mathrm{WORE}+\beta_{7} \mathrm{LACQ}+\beta_{8} \mathrm{AGE}+\beta_{9} \mathrm{PLAQ}+\beta_{10} \mathrm{INCO}+\varepsilon
\end{gathered}
$$

Where:

$\begin{array}{lll}\text { JSAT } & : & \text { Job satisfaction. } \\ \beta_{0} & : & \text { Constant } \\ \mathrm{B}_{1}-\mathrm{B}_{10} & : & \text { Parameters of the model } \\ \text { NAT } & : & \text { Nationality } \\ \text { UNIV } & : & \text { University status whether public or private university } \\ \text { GEN } & : & \text { Gender } \\ \text { MARS } & : & \text { Marital Status } \\ \text { ACCR } & : & \text { Academic Rank } \\ \text { WORE } & : & \text { Work Experience } \\ \text { LACQ } & : & \text { Last Academic Qualification } \\ \text { AGE } & : & \text { Age } \\ \text { PLAQ } & : & \text { Place Where the Last Academic Qualification Obtained } \\ \text { INCO } & : \text { Income } \\ \varepsilon & : & \text { Standard Error }\end{array}$

Backward regression is an elimination regression that starts with all variables employed to estimate the regression model. It then deletes the least significant variables until it gives the best-fit model with the remaining variables being statistically significant in estimating the dependent variable.

\section{Findings}

\subsection{Respondents background}

Table (2) summarizes the main characteristics of the respondents who took part in the questionnaire. It can be observed in the table that the vast majority of the respondents (56\%) are non-Kuwaitis and work for private universities (70\%). This reflects the sample used in the current study that covers 8 business colleges, only two of them are governmental and the remaining are private colleges. While Kuwaiti nationals are dominant in the government universities, non-Kuwaitis are dominant in private universities. The vast majority $(64 \%)$ is males and hold $\mathrm{PhD}(66 \%)$. In addition $56 \%$ of the respondents are married and almost $67 \%$ of them age between 25 and 50 years. Most of the respondents $(64 \%)$ obtained their last academic degree either from American or British universities. This reflects the education policy of the Kuwaiti government that directs its scholarship on American and British universities. In addition, Kuwaiti universities whether governmental or private recruit American and British graduates since these universities offer their academic programs in English and adopt either the American or British system of higher education. One third of the respondents are in the lecturer rank. In general, lecturers hold masters degrees and they are involved in teaching general courses. $40 \%$ of the respondents to the questionnaire are in the rank of assistant professor; whereas, $12 \%$ and $17 \%$ of the respondents are associate and full professors respectively. Once again, this result is predictable since business colleges in Kuwaiti offer either two years Diploma or Bachelor degree. A limited number of these colleges offer Masters Degree (MBA). Academicians in the rank of assistant professor have enough knowledge and skills to teach on these programs; bearing in mind that almost $70 \%$ of the respondents have more than 5 years of work experience. What attracts attention in Table (2) is the salary scale of the respondents and the number of years passed since they attained the last promotion. More than $60 \%$ of the respondents earn more than KD 2,000 (almost \$7,000) monthly. In addition to the monthly salary, Kuwaiti universities offer non-Kuwaiti lecturers accommodation allowance, transportation, travel, internet, up to two children school fees and medical insurance. A significant proportion of the respondents (39\%) indicated that they had attained their last promotion more than 6 years ago.

\begin{tabular}{|c|c|c|c|c|c|}
\hline & Freq. & Percent & & Freq. & Percent \\
\hline Nationality & & & Gender & & \\
\hline Kuwaiti & 61 & 43.3 & Female & 51 & 36.2 \\
\hline Non-Kuwaiti & $\underline{80}$ & $\underline{56.7}$ & Male & $\underline{90}$ & $\underline{63.8}$ \\
\hline Total & $\underline{\underline{141}}$ & $\underline{\underline{100}}$ & Total & $\underline{\underline{141}}$ & $\underline{\underline{100.0}}$ \\
\hline
\end{tabular}

Table 2. Respondents Background 


\begin{tabular}{|c|c|c|}
\hline \multicolumn{3}{|l|}{ Academic Qualifications } \\
\hline Masters & 48 & 34.0 \\
\hline PhD. & $\underline{93}$ & $\underline{66.0}$ \\
\hline Total & $\underline{141}$ & $\underline{\underline{100.0}}$ \\
\hline \multicolumn{3}{|l|}{ Academic Rank } \\
\hline Lecturer & 43 & 30.5 \\
\hline Assistant Professor & 57 & 40.4 \\
\hline Associate Professor & 17 & 12.1 \\
\hline Full Professor & $\underline{24}$ & $\underline{17.0}$ \\
\hline Total & $\underline{141}$ & $\underline{100.0}$ \\
\hline \multicolumn{3}{|c|}{ Place where last academic degree obtained } \\
\hline Arab countries & 23 & 16.3 \\
\hline USA & 56 & 39.7 \\
\hline UK & 34 & 24.1 \\
\hline European other than UK & 8 & 5.7 \\
\hline Others & $\underline{20}$ & 14.2 \\
\hline Total & $\underline{\underline{141}}$ & $\underline{\underline{100.0}}$ \\
\hline \multicolumn{3}{|l|}{ Salary } \\
\hline less than $\mathrm{KD} 1,500$ & 20 & 14.2 \\
\hline Between KD 1500-2000 & 36 & 25.5 \\
\hline Between KD 2001-3000 & 67 & 47.5 \\
\hline More than KD 3000 & $\underline{18}$ & $\underline{12.8}$ \\
\hline \multicolumn{3}{|l|}{ University Ownership } \\
\hline Government & 42 & 29.8 \\
\hline \multirow[t]{2}{*}{ Private } & $\underline{99}$ & $\underline{70.2}$ \\
\hline & $\underline{\underline{141}}$ & $\underline{\underline{100.0}}$ \\
\hline Total & $\underline{141}$ & $\underline{100.0}$ \\
\hline
\end{tabular}

\begin{tabular}{lrc} 
Marital Status & & \\
Single & 47 & 33.3 \\
Married & $\underline{94}$ & $\underline{\underline{55.7}}$ \\
Total & $\underline{\underline{\mathbf{1 4 1}}}$ & $\underline{\underline{\mathbf{1 0 0 . 0}}}$ \\
\hline
\end{tabular}

\begin{tabular}{lcc} 
Age & & \\
Less than 25 Years & 1 & 0.7 \\
Between 25-39 years & 37 & 26.2 \\
between 39- 50 years & 57 & 40.4 \\
More than 50 years & $\underline{46}$ & $\underline{\underline{32.6}}$ \\
Total & $\underline{\underline{\mathbf{1 4}}}$ & $\underline{\underline{\mathbf{1 0 0 . 0}}}$ \\
\hline \multicolumn{4}{l}{ Year(s) since your last promotion } \\
\hline Less than one year & 20 & 14.2 \\
1-3 years & 42 & 29.8 \\
4-6 years & 24 & 17.0 \\
More than 6 years & $\underline{\mathbf{5 5}}$ & $\underline{39.0}$ \\
& $\underline{\mathbf{1 4 1}}$ & $\underline{\mathbf{1 0 0 . 0}}$ \\
\hline
\end{tabular}

\section{Years of work experience}

\begin{tabular}{lcc} 
Less than 1 year & 6 & 4.3 \\
1- 5 yeas & 34 & 24.1 \\
6-10 years & 36 & 25.5 \\
More than 10 years & $\underline{65}$ & $\underline{45.1}$ \\
\hline
\end{tabular}

Respondents' Level of Job Satisfaction

Before exploring the effect of the respondents' level of job satisfaction and the effect of their characteristics on the extent of job satisfaction, it was important to measure the internal consistency (reliability) of the collected data; Cronbach's Alpha $(\alpha)$ was performed and touched 0.929. In general, a commonly acceptable Cronbach's Alpha $(\alpha)$ is $\geq$ 0.70 .

Table (3) reports respondents' level of satisfaction with different aspects of their job. It is clear from the table that the respondents reached a relatively high level of satisfaction with all aspects included in the questionnaire except for advancement in their job as reflected by the reported means. Combining all aspects of job satisfaction together results in almost $68.42 \%$ overall score. In other word, if job satisfaction is defined as the extent to which the job meets the surveyed academicians' expectations, it satisfies $68 \%$ of their expectations. In addition to the advancement aspect of job satisfaction, the respondents appeared to be less satisfied with recognition, college policies and practices, supervision-technical, authority and variety. The result in similar to a conclusion reached by Bader (1983) who conducted a job satisfaction study in Kuwait University and found academicians are less satisfied with promotion opportunities, decision-making and advancement. The result is also in partial support of results achieved by Oshagbemi $(1996,2003)$ who found academicians in the UK are moderately satisfied with department heads' behavior and dissatisfied with promotion and performance. Furthermore, Eyupoglu and Saner (2009) observed that academicians in Pakistan are dissatisfied with promotion opportunities. The result is not surprising and reflects the Arab culture. For instance, in the Arab universities advancements in jobs is dodgy and promotion is influenced by personal and, in some occasions, by political factors. In Kuwait and other GCC countries, personal connections, rather than political considerations, play an active role in recruitment and advancement. Kuwait is a small society and they know each other closely. The weekly gatherings (deawaniat) that characterizes Kuwaiti society are playing an active role in facilitating the Kuwaitis daily aspects of life. Regular members of each of these gathering (dewaniah) are expected to help each other. Social status of the family of the lecturer who seeks promotion or the intermediary between the one who seeks promotion and the concerned body (college dean) could be more important in achieving promotion than what applicant for a promotion had achieved. In some cases, it is possible to have a head of department and a college dean with less academic qualifications and experience than many of his/ her subordinates. In this case, promoting faculty members means that they reached higher academic ranks than him/ her. Highly performed 
academicians who feel that they stand a little chance of advancement in their job will be less satisfied and they will look for other universities that appreciate their academic performance. Hence, the university ends up retaining less performed academicians. This will lower the university's academic level and makes it difficult to achieve the main objective of the higher education system. To prevent this from happening, the head of department and the dean will put obstacles towards any academic advancement or promotion. To avoid this problem, clear guidelines about academic promotion would be spelled out in the college's policies and procedures. In addition, the promotion committee should be formed at the university level with representatives from all colleges. The members of the promotion committee should be in the rank of full professor. To ensure transparency and to achieve the highest level of quality control, the university can seek the help of external assessors from credible universities outside the country according to specialization. Hence, the promotion committee can rely on the external assessors report when making their final decision about the application of an academic staff for a promotion. By doing so, the university prevents ambiguity about promotion requirements and minimizes social pressure that might come from an influential personality or any other pressure groups. This is expected to enhance academicians' trust of the education system within their college and boost the level of their job satisfaction. The college will succeed in retaining good lecturers and this will achieve the main objective of the country's higher education system.

The respondents seem, however, to be highly satisfied with the social service and social status, independence, achievement and activity aspects of their jobs. This result is generally in line with Zarafshani and Alibaygi (2008), Eyupoglu and Saner (2009) and Toker (2011) who found academicians are satisfied with the social service aspect of job satisfaction. However, the respondents to the current study expressed moderate satisfaction with compensation, supervision, co-workers, authority and variety.

Table 3. The importance all participants attach to different items of job satisfaction

\begin{tabular}{|c|c|c|c|c|}
\hline & Mean & Median & Std. Deviation & Rank \\
\hline \multicolumn{5}{|l|}{ Ability utilization: The chance to do something that makes use of my abilities } \\
\hline Achievement: The feeling of accomplishment I get from the job. & 3.73 & 4.00 & 0.91 & 3 \\
\hline Activity: Being able to keep busy all the time. & 3.65 & 4.00 & 0.98 & 5 \\
\hline Advancement: The chance for advancement on this job. & 2.95 & 3.00 & 1.12 & 20 \\
\hline Authority: The chance to tell other people what to do. & 3.23 & 3.00 & 0.99 & 16 \\
\hline Company policies and practices: The way university policies are put into practice. & 3.19 & 3.00 & 1.01 & 17 \\
\hline Compensation: My pay reflects the work I do. & 3.42 & 3.00 & 1.12 & 10 \\
\hline Co-workers: The way my co-workers get along with each other & 3.28 & 3.00 & 1.07 & 13 \\
\hline Creativity: The chance to try my own methods of doing the job. & 3.55 & 4.00 & 1.00 & 7 \\
\hline Independence: The chance to work alone on the job. & 3.71 & 4.00 & 1.02 & 4 \\
\hline Moral values: Being able to do things that don't go against my conscience & 3.51 & 3.00 & 1.04 & 8 \\
\hline Recognition: The praise I get from doing a good job. & 3.16 & 3.00 & 1.15 & 19 \\
\hline Responsibility: The freedom to use my own judgment. & 3.28 & 3.00 & 1.10 & 13 \\
\hline Security: The way my job provides for steady employment. & 3.59 & 4.00 & 1.12 & 6 \\
\hline Social service: The chance to do things for other people. & 3.81 & 4.00 & 0.88 & 1 \\
\hline Social status: The chance to be "somebody" in the community. & 3.74 & 4.00 & 0.99 & 2 \\
\hline Supervision-human relations: The way my boss handles his/her workers. & 3.32 & 3.00 & 1.15 & 12 \\
\hline Supervision-technical: The competence of my supervisor in making decisions. & 3.16 & 3.00 & 1.07 & 17 \\
\hline Variety: The chance to do different things from time to time. & 3.24 & 3.00 & 1.01 & 15 \\
\hline Working conditions & 3.42 & 3.00 & 1.04 & 10 \\
\hline
\end{tabular}

3.2 Level of Job Satisfaction and Respondents' Characteristics and the

The level of the respondents' job satisfaction and their characteristics is reported in Table (4). In terms of the respondents' nationality, the table showed non-Kuwaitis are more satisfied than Kuwaitis as reflected by the overall score of various aspects of job satisfaction. The table further shows academicians who work for private universities are more satisfied than those who work for governmental universities. In this respect, Khalid et al. (2012) found academicians in private universities are more satisfied with their pay, supervision, and promotional opportunities than academicians in public universities. The result is explained on the grounds that most of the academic staff in private universities are non-Kuwaitis. Hence, it is not surprising to see private universities academicians are more satisfied than governmental universities. Non-Kuwaiti academicians have many reasons to be satisfied. In addition to the relatively high salaries they earn, they benefit from accommodation allowance, children education, travel expenses, internet and utilities allowance. They further benefit from the low cost of living and zero income tax. Kuwaiti nationals are less satisfied than non-Kuwaitis due to nature of the disciplinary nature of the academicians' jobs. In other words, it is easy to identify whether a lecturer attended his/ her lecture or whether he/ she is available during the publicized office hours designed for students to consult their lecturer. This acts against the nature of the Kuwaitis who prefer flexible jobs that allows them to come and go whenever at their convenience. 
Table (4) shows females and single respondents are more satisfied than males and married respondents. This result is explained on the ground that Kuwait as a conservative small country has limited job opportunities for non-Kuwaiti females since priority whether in the public sector or the private sector is given to the Kuwaiti nationals. Hence, females' qualified lectures are more likely to find decent jobs in private universities. Work environment in the Kuwaiti private universities are suitable for female lecturers since they are highly qualified and they do not face strong competition with local lecturers. In addition, the compensation package offered by private universities to lecturers in general, whether males or females, are compatible with regional or even western universities. Academic infrastructure in Kuwaiti universities, as well as all GCC universities are also compatible with top western universities and the revolution in information technology assist these lecturers to become active in conducting research. Finally, Kuwait has an advanced infrastructure. It is a secured country with high standard and a relatively low cost living and zero income tax. This result is in support of Ward and Sloane (2000) and Santhapparaj and Alam (2005) who observed women to be generally more satisfied than their males counterparts. Malik (2011) also noticed that male faculty members are less satisfied than female faculty members. In this regards, Noordin and Jusoff (2009) noticed marital status and gender to be significant determinants of job satisfaction. They, however, noticed that the males have a significantly higher level of general satisfaction than their female counterparts. Al-Rubaish et al. (2009) initiated that females were significantly less satisfied than their male counterparts. On the other hand, Stevens (2005) reported insignificant difference in the level of job satisfaction between male and female academicians. Similarly, Toker (2011) also reported insignificant relationship between job satisfaction and marital status and gender. Insignificant association between gender and job satisfaction also was observed by Saygi et al. (2011). Sseganga (2003) and Abushaira (2012) found no evidence to support the relationship between gender and job satisfaction. Similarly, Bader (1983) found insignificant relationship between job satisfaction and material status, age and gender. Zayed (2008) noticed that married academicians are less job satisfied than single one.

Table (4) highlighted that respondents aged between 25-39 and more than 50 years are more satisfied than those who are between 40-50 years old. This result is understandable since young academicians generally have few responsibilities than well-established colleagues and they are still at beginning steps of the promotion ladder. Hence, they have few problems than those who are half the way through the promotion ladder who have more responsibilities and worry about future promotions. Academicians more than 50 years old are expected to be well-established, attained the highest academic promotions and highly paid. Hence, it is not surprising to see him highly satisfied with their jobs. Noordin and Jusoff (2009) and Abushaira (2012) established significant differences in the level of job satisfaction due to age difference. Malik (2011), however, noticed that age is insignificantly related to overall job satisfaction.

The table shows respondents earn more than KD 4,500 expressed the highest level of job satisfaction; whereas, respondents earn less than KD 1,500 were the least satisfied. However, respondents who earn between KD 1,500-3,000 expressed higher level of job satisfaction than those who earn between KD 3,001-4,500. This might be due to fact that the respondents within this category are more likely to be in the highest rank of assistance professor or they are associate professors but found it difficult to advance to the following academic rank. Respondents at the full professor level showed the highest level of satisfaction followed by associate professors. This result is in line with Mehmood et al. (2012) who pointed to a relationship between employees' job satisfaction and their salaries. Zayed (2008) found income as the most important determinant of academicians' job satisfaction.

When considering the relationship between academic rank and job satisfaction, table (4) revealed that respondents in the rank of full professors are the most satisfied and the assistant professors are the least satisfied. This result is comprehensible since academicians at the full professor rank have already achieved the highest advancements and they are expected to be paid more than associate and assistant professors. Although some of the associate professor might be frustrated due to slow advancement, many of the respondents would be promoted recently or they are not yet due for promotion. Furthermore, slow advancement might be compensated with other aspects of job satisfaction. What is important to notice in the table is that respondents at the lecturer level are more satisfied with their job than assistant professors. The result can be explained on the ground that lecturers are generally hold Masters degree and they do not expect any change in their academic rank unless thy obtain PhDs. Hence, they are expected to be less frustrated than assistant professors who are waiting for promotion to the associate professor level. The result is in support of previous research undertaken by Oshagbemi $(1996,2003)$ and demonstrated that academicians' rank is a significant determinant of their level of satisfaction. This is also in support of Stevens (2005) and Toker (2011) who found professors are generally happier in their jobs than their colleagues at lower academic ranks. Yet, Malik (2011) indicated that academicians demographic characteristics such as age, years of experience, academic rank and academic qualifications are negligibly related to the overall job satisfaction.

As for the effect of the respondents work experience on the level of satisfaction, table (4) revealed that respondents with more than 10 years and between 1-5 years of work experience are the most satisfied ones. Respondents with less than 1 year and 6-10 years of work experience are the least satisfied. The result is highly associated with other variables such as monthly income and academic rank. For those who have less than 1 year of work experience they are expected to have low income and to wait for a while before achieving any promotion. Respondents who have 6-10 years of work experience are more likely to be in the rank of associate professor and waiting for promotion to full professor. Hence, they are expected to have low level of job satisfaction. This result is in line with Oshagbemi (1996, 
2003) who indicated that the length of service is a significant predictor of academicians' level of satisfaction. Yet, Zayed (2008) noticed that academicians with less than five years of service are more satisfied than their counterparts who have more than five years. Similarly, lecturers who hold Masters degree will have low salary and they have limited prospect of any future advancement. Their low level of job satisfaction in comparison with respondents who hold doctorate degrees is predictable. This result is inconsistent with Ward and Sloane (2000) who reported a decline in job satisfaction with level of education.

The result of the questionnaire analysis reported in table (4) revealed that respondents who obtained their last academic degree from USA and UK and more satisfied than graduates from other countries. It is a common practice in the Gulf Universities including Kuwait to give priority to American and British Universities graduates. In addition, the higher education system in the Kuwaiti universities is influenced by the USA and UK systems of education. This gives graduates from these two countries priority in the recruitment phase and their familiarity with the education system assists them in attaining quick advancements.

Finally, table (4) illustrates the effect of waiting time since the respondents achieved their last academic promotion on the level of job satisfaction. While respondents who were waiting less than one year or between 1-3 years are the most satisfied with their job, respondents who received their last promotion more than 6 years ago or between 4-6 years ago are the least satisfied. This is an anticipated result since the more the academicians wait for their promotion the more they get frustrated and this will affect their level of job satisfaction. Needless to say, achieving promotion has income, recognition and social implications.

Table 4. Participants characteristics and the level of job satisfaction

\begin{tabular}{|c|c|c|c|c|c|c|c|c|c|c|c|c|}
\hline & \multicolumn{3}{|c|}{ Nationality } & \multicolumn{2}{|c|}{ University Status } & \multicolumn{2}{|c|}{ Gender } & \multicolumn{2}{|c|}{ Marital Status } & \multicolumn{3}{|c|}{ Age } \\
\hline & All & Kuwaiti & Non-Kuwaiti & $\begin{array}{l}\text { State } \\
\text { Univ. }\end{array}$ & $\begin{array}{l}\text { Private } \\
\text { Univ. }\end{array}$ & Male & Female & Single & Married & $25-39$ & $40-50$ & $\begin{array}{c}\text { More } \\
\text { than } \\
50\end{array}$ \\
\hline $\begin{array}{l}\text { Ability utilization: The chance to } \\
\text { do something that makes use of my } \\
\text { abilities }\end{array}$ & 3.48 & 3.18 & 3.71 & 3.33 & 3.55 & 3.31 & 3.78 & 3.60 & 3.43 & 3.73 & 3.30 & 3.50 \\
\hline $\begin{array}{l}\text { Achievement: The feeling of } \\
\text { accomplishment I get from the job. }\end{array}$ & 3.73 & 3.57 & 3.85 & 3.62 & 3.78 & 3.66 & 3.86 & 3.77 & 3.71 & 3.78 & 3.65 & 3.78 \\
\hline $\begin{array}{l}\text { Activity: Being able to keep busy } \\
\text { all the time. }\end{array}$ & 3.65 & 3.51 & 3.76 & 3.60 & 3.68 & 3.62 & 3.71 & 3.72 & 3.62 & 3.76 & 3.49 & 3.78 \\
\hline $\begin{array}{l}\text { Advancement: The chance for } \\
\text { advancement on this job. }\end{array}$ & 2.95 & 2.69 & 3.15 & 2.81 & 3.01 & 2.84 & 3.14 & 3.04 & 2.90 & 3.08 & 2.79 & 3.04 \\
\hline $\begin{array}{l}\text { Authority: The chance to tell other } \\
\text { people what to do. } \\
\text { Company policies and practices: }\end{array}$ & 3.23 & 3.08 & 3.35 & 3.12 & 3.28 & 3.18 & 3.33 & 3.43 & 3.14 & 3.14 & 3.11 & 3.48 \\
\hline $\begin{array}{l}\text { The way university policies are put } \\
\text { into practice. }\end{array}$ & 3.19 & 2.89 & 3.43 & 2.81 & 3.35 & 3.08 & 3.39 & 3.43 & 3.07 & 3.32 & 2.96 & 3.37 \\
\hline $\begin{array}{l}\text { Compensation: My pay reflects the } \\
\text { work I do. }\end{array}$ & 3.42 & 3.25 & 3.55 & 3.48 & 3.39 & 3.41 & 3.43 & 3.51 & 3.37 & 3.41 & 3.33 & 3.54 \\
\hline $\begin{array}{l}\text { Co-workers: The way my } \\
\text { co-workers get along with each } \\
\text { other }\end{array}$ & 3.28 & 3.05 & 3.45 & 3.05 & 3.37 & 3.19 & 3.43 & 3.49 & 3.17 & 3.27 & 3.18 & 3.41 \\
\hline $\begin{array}{l}\text { Creativity: The chance to try my } \\
\text { own methods of doing the job. }\end{array}$ & 3.55 & 3.41 & 3.65 & 3.67 & 3.49 & 3.51 & 3.61 & 3.64 & 3.50 & 3.57 & 3.37 & 3.74 \\
\hline $\begin{array}{l}\text { Independence: The chance to work } \\
\text { alone on the job. }\end{array}$ & 3.71 & 3.72 & 3.70 & 4.02 & 3.58 & 3.64 & 3.82 & 3.77 & 3.68 & 3.81 & 3.39 & 4.02 \\
\hline $\begin{array}{l}\text { Moral values: Being able to do } \\
\text { things that don't go against my } \\
\text { conscience }\end{array}$ & 3.51 & 3.46 & 3.55 & 3.67 & 3.44 & 3.37 & 3.76 & 3.57 & 3.48 & 3.62 & 3.26 & 3.72 \\
\hline $\begin{array}{l}\text { Recognition: The praise I get from } \\
\text { doing a good job. }\end{array}$ & 3.16 & 2.74 & 3.48 & 2.79 & 3.31 & 2.96 & 3.51 & 3.45 & 3.01 & 3.35 & 2.96 & 3.22 \\
\hline $\begin{array}{l}\text { Responsibility: The freedom to use } \\
\text { my own judgment. }\end{array}$ & 3.28 & 3.30 & 3.26 & 3.52 & 3.17 & 3.20 & 3.41 & 3.38 & 3.22 & 3.27 & 3.04 & 3.57 \\
\hline $\begin{array}{l}\text { Security: The way my job provides } \\
\text { for steady employment. }\end{array}$ & 3.59 & 3.79 & 3.44 & 4.26 & 3.30 & 3.49 & 3.76 & 3.51 & 3.63 & 3.68 & 3.42 & 3.74 \\
\hline $\begin{array}{l}\text { Social service: The chance to do } \\
\text { things for other people. }\end{array}$ & 3.81 & 3.82 & 3.80 & 3.98 & 3.74 & 3.78 & 3.86 & 3.91 & 3.76 & 4.03 & 3.65 & 3.85 \\
\hline $\begin{array}{l}\text { Social status: The chance to be } \\
\text { "somebody" in the community. }\end{array}$ & 3.74 & 3.95 & 3.59 & 4.02 & 3.63 & 3.83 & 3.59 & 3.64 & 3.80 & 3.73 & 3.67 & 3.87 \\
\hline $\begin{array}{l}\text { Supervision-human relations: The } \\
\text { way my boss handles his/her } \\
\text { workers. }\end{array}$ & 3.32 & 3.07 & 3.51 & 3.02 & 3.44 & 3.17 & 3.59 & 3.43 & 3.27 & 3.70 & 2.91 & 3.52 \\
\hline $\begin{array}{l}\text { Supervision-technical: The } \\
\text { competence of my supervisor in } \\
\text { making decisions. }\end{array}$ & 3.16 & 2.93 & 3.34 & 3.05 & 3.21 & 3.04 & 3.37 & 3.45 & 3.02 & 3.27 & 2.89 & 3.41 \\
\hline $\begin{array}{l}\text { Variety: The chance to do different } \\
\text { things from time to time. }\end{array}$ & 3.24 & 2.90 & 3.50 & 3.07 & 3.31 & 3.12 & 3.45 & 3.40 & 3.16 & 3.24 & 3.02 & 3.52 \\
\hline Working conditions & 3.42 & 3.23 & 3.56 & 3.33 & 3.45 & 3.40 & 3.45 & 3.57 & 3.34 & 3.38 & 3.19 & 3.74 \\
\hline Overall Score & 68.42 & 65.52 & 70.63 & 68.21 & 68.51 & 66.80 & 71.27 & 70.70 & 67.28 & 70.14 & 64.58 & 71.83 \\
\hline
\end{tabular}




\begin{tabular}{|c|c|c|c|c|c|c|c|c|c|c|c|c|}
\hline & \multicolumn{4}{|c|}{ Monthly Income } & \multicolumn{4}{|c|}{ Academic Rank } & \multicolumn{4}{|c|}{ Work Experience } \\
\hline & $\begin{array}{l}\text { Less } \\
\text { than } \\
\mathrm{KD} \\
1,500\end{array}$ & $\begin{array}{c}\mathrm{KD} \\
1,500- \\
3,000\end{array}$ & $\begin{array}{c}\mathrm{KD} \\
3001-4,500\end{array}$ & $\begin{array}{l}\text { More } \\
\text { than } \\
\text { KD } \\
4,500\end{array}$ & Lecturer & $\begin{array}{l}\text { Assis. } \\
\text { Prof. }\end{array}$ & $\begin{array}{l}\text { Assoc. } \\
\text { Prof. }\end{array}$ & $\begin{array}{l}\text { Full } \\
\text { Prof. }\end{array}$ & $\begin{array}{c}\text { Less } \\
\text { than } 1 \\
\text { year }\end{array}$ & $\begin{array}{c}1-5 \\
\text { Years }\end{array}$ & $\begin{array}{l}6-10 \\
\text { Years }\end{array}$ & $\begin{array}{c}\text { More } \\
\text { than } \\
10 \\
\text { years }\end{array}$ \\
\hline $\begin{array}{l}\text { Ability utilization: The } \\
\text { chance to do something that } \\
\text { makes use of my abilities }\end{array}$ & 3.35 & 3.47 & 3.49 & 3.61 & 3.51 & 3.44 & 3.21 & 3.94 & 3.50 & 3.59 & 3.47 & 3.43 \\
\hline $\begin{array}{l}\text { Achievement: The feeling } \\
\text { of accomplishment I get } \\
\text { from the job. }\end{array}$ & 3.55 & 3.75 & 3.72 & 3.94 & 3.77 & 3.65 & 3.75 & 3.88 & 3.67 & 3.62 & 3.81 & 3.75 \\
\hline $\begin{array}{l}\text { Activity: Being able to keep } \\
\text { busy all the time. }\end{array}$ & 3.15 & 3.67 & 3.69 & 4.06 & 3.51 & 3.72 & 3.71 & 3.71 & 3.67 & 3.62 & 3.67 & 3.66 \\
\hline $\begin{array}{l}\text { Advancement: The chance } \\
\text { for advancement on this } \\
\text { job. }\end{array}$ & 2.45 & 3.14 & 3.00 & 2.94 & 2.77 & 2.86 & 3.25 & 3.29 & 2.33 & 3.15 & 2.69 & 3.05 \\
\hline $\begin{array}{l}\text { Authority: The chance to } \\
\text { tell other people what to do. }\end{array}$ & 2.85 & 3.44 & 3.24 & 3.22 & 3.23 & 3.21 & 3.13 & 3.47 & 2.67 & 3.29 & 3.19 & 3.28 \\
\hline $\begin{array}{l}\text { Company policies and } \\
\text { practices: The way } \\
\text { university policies are put } \\
\text { into practice. }\end{array}$ & 3.20 & 3.31 & 3.18 & 3.00 & 3.30 & 3.12 & 2.96 & 3.47 & 2.50 & 3.38 & 3.22 & 3.14 \\
\hline $\begin{array}{l}\text { Compensation: My pay } \\
\text { reflects the work I do. }\end{array}$ & 2.90 & 3.25 & 3.57 & 3.78 & 3.37 & 3.11 & 3.88 & 3.94 & 2.33 & 3.38 & 3.31 & 3.60 \\
\hline $\begin{array}{l}\text { Co-workers: The way my } \\
\text { co-workers get along with } \\
\text { each other }\end{array}$ & 3.05 & 3.47 & 3.31 & 3.00 & 3.37 & 3.16 & 3.33 & 3.35 & 3.17 & 3.29 & 3.22 & 3.31 \\
\hline $\begin{array}{l}\text { Creativity: The chance to } \\
\text { try my own methods of } \\
\text { doing the job. }\end{array}$ & 3.35 & 3.44 & 3.49 & 4.17 & 3.37 & 3.51 & 3.71 & 3.88 & 3.50 & 3.50 & 3.44 & 3.63 \\
\hline $\begin{array}{l}\text { Independence: The chance } \\
\text { to work alone on the job. }\end{array}$ & 3.30 & 3.72 & 3.63 & 4.44 & 3.67 & 3.61 & 3.83 & 3.94 & 3.83 & 3.50 & 3.67 & 3.83 \\
\hline $\begin{array}{l}\text { Moral values: Being able to } \\
\text { do things that don't go } \\
\text { against my conscience }\end{array}$ & 3.10 & 3.50 & 3.49 & 4.06 & 3.49 & 3.40 & 3.46 & 4.00 & 3.83 & 3.50 & 3.28 & 3.62 \\
\hline $\begin{array}{l}\text { Recognition: The praise I } \\
\text { get from doing a good job. }\end{array}$ & 3.55 & 3.44 & 2.97 & 2.83 & 3.26 & 3.04 & 2.92 & 3.65 & 3.50 & 3.12 & 2.94 & 3.26 \\
\hline $\begin{array}{l}\text { Responsibility: The } \\
\text { freedom to use my own } \\
\text { judgment. }\end{array}$ & 3.25 & 3.36 & 3.07 & 3.89 & 3.33 & 3.19 & 3.33 & 3.35 & 3.83 & 3.26 & 2.81 & 3.49 \\
\hline $\begin{array}{l}\text { Security: The way my job } \\
\text { provides for steady } \\
\text { employment. }\end{array}$ & 3.35 & 3.39 & 3.49 & 4.61 & 3.53 & 3.54 & 3.67 & 3.76 & 3.83 & 3.50 & 3.33 & 3.75 \\
\hline $\begin{array}{l}\text { Social service: The chance } \\
\text { to do things for other } \\
\text { people. }\end{array}$ & 3.75 & 3.78 & 3.76 & 4.11 & 3.84 & 3.77 & 3.75 & 3.94 & 4.17 & 3.85 & 3.67 & 3.83 \\
\hline $\begin{array}{l}\text { Social status: The chance to } \\
\text { be "somebody" in the } \\
\text { community. }\end{array}$ & 3.35 & 3.83 & 3.66 & 4.33 & 3.65 & 3.74 & 3.88 & 3.82 & 3.50 & 3.62 & 3.69 & 3.86 \\
\hline $\begin{array}{l}\text { Supervision-human } \\
\text { relations: The way my boss } \\
\text { handles his/her workers. }\end{array}$ & 3.80 & 3.61 & 3.12 & 2.94 & 3.56 & 3.07 & 3.33 & 3.53 & 3.00 & 3.38 & 3.25 & 3.35 \\
\hline $\begin{array}{l}\text { Supervision-technical: The } \\
\text { competence of my } \\
\text { supervisor in making } \\
\text { decisions. }\end{array}$ & 3.30 & 3.42 & 3.00 & 3.11 & 3.26 & 2.98 & 3.29 & 3.35 & 3.00 & 3.06 & 2.97 & 3.34 \\
\hline $\begin{array}{l}\text { Variety: The chance to do } \\
\text { different things from time } \\
\text { to time. }\end{array}$ & 3.15 & 3.31 & 3.15 & 3.56 & 3.16 & 3.11 & 3.46 & 3.59 & 2.17 & 3.15 & 3.17 & 3.43 \\
\hline Working conditions & 3.00 & 3.83 & 3.28 & 3.56 & 3.47 & 3.19 & 3.71 & 3.65 & 2.67 & 3.41 & 3.17 & 3.63 \\
\hline Overall Score & 64.75 & 70.14 & 67.31 & 73.17 & 68.42 & 66.42 & 69.54 & 73.53 & 64.67 & 68.18 & 65.97 & 70.25 \\
\hline
\end{tabular}

\begin{tabular}{|c|c|c|c|c|c|c|c|c|c|c|c|}
\hline & \multicolumn{2}{|c|}{ Academic Degree } & \multicolumn{5}{|c|}{ Place where last academic degree obtained } & \multicolumn{4}{|c|}{$\begin{array}{c}\text { Years since last academic } \\
\text { qualification }\end{array}$} \\
\hline & Masters & $\mathrm{PhD}$. & $\begin{array}{l}\text { Arab } \\
\text { Country }\end{array}$ & USA & UK & Canada & $\begin{array}{c}\text { European } \\
\text { non-UK }\end{array}$ & $\begin{array}{l}\text { Less } \\
\text { than } 1\end{array}$ & $\begin{array}{c}1-3 \\
\text { years }\end{array}$ & $\begin{array}{c}\text { 4-6 } \\
\text { years }\end{array}$ & $\begin{array}{l}\text { More } \\
\text { than } 6 \\
\text { years }\end{array}$ \\
\hline $\begin{array}{l}\text { Ability utilization: The chance to do } \\
\text { something that makes use of my } \\
\text { abilities }\end{array}$ & 3.40 & 3.54 & 3.30 & $\begin{array}{c}3 \\
1 / 2\end{array}$ & 3.50 & 3.25 & 3.45 & 3.45 & 3.60 & 3.71 & 3.30 \\
\hline $\begin{array}{l}\text { Achievement: The feeling of } \\
\text { accomplishment I get from the job. }\end{array}$ & 3.70 & 3.75 & 3.52 & $\begin{array}{c}3 \\
3 / 4\end{array}$ & 3.71 & 3.38 & 3.91 & 3.75 & 3.81 & 3.79 & 3.60 \\
\hline Activity: Being able to keep busy all & 3.40 & 3.79 & 3.30 & 3 & 3.91 & 3.00 & 3.00 & 3.85 & 3.60 & 3.71 & 3.58 \\
\hline
\end{tabular}




\begin{tabular}{|c|c|c|c|c|c|c|c|c|c|c|c|}
\hline the time. & & & & $3 / 4$ & & & & & & & \\
\hline $\begin{array}{l}\text { Advancement: The chance for } \\
\text { advancement on this job. }\end{array}$ & 2.70 & 3.08 & 2.65 & 3 & 3.18 & 3.25 & 2.36 & 2.55 & 3.19 & 3.00 & 2.96 \\
\hline $\begin{array}{l}\text { Authority: The chance to tell other } \\
\text { people what to do. }\end{array}$ & 3.09 & 3.32 & 2.96 & $\begin{array}{c}3 \\
1 / 3\end{array}$ & 3.50 & 2.88 & 2.64 & 2.85 & 3.24 & 3.42 & 3.34 \\
\hline $\begin{array}{l}\text { Company policies and practices: } \\
\text { The way university policies are put } \\
\text { into practice. }\end{array}$ & 3.23 & 3.18 & 3.00 & $\begin{array}{c}3 \\
1 / 4\end{array}$ & 3.29 & 3.25 & 2.73 & 2.85 & 3.31 & 3.63 & 3.04 \\
\hline $\begin{array}{l}\text { Compensation: My pay reflects the } \\
\text { work I do. }\end{array}$ & 3.23 & 3.52 & 3.04 & $\begin{array}{c}3 \\
3 / 5\end{array}$ & 3.35 & 3.38 & 3.09 & 3.00 & 3.40 & 3.54 & 3.56 \\
\hline $\begin{array}{l}\text { Co-workers: The way my } \\
\text { co-workers get along with each } \\
\text { other }\end{array}$ & 3.17 & 3.3587 & 2.91 & $\begin{array}{c}3 \\
3 / 8\end{array}$ & 3.41 & 3.25 & 2.82 & 3.15 & 3.36 & 3.33 & 3.24 \\
\hline $\begin{array}{l}\text { Creativity: The chance to try my } \\
\text { own methods of doing the job. }\end{array}$ & 3.23 & 3.7174 & 3.17 & $\begin{array}{c}3 \\
2 / 3\end{array}$ & 3.56 & 3.13 & 3.64 & 3.55 & 3.43 & 3.63 & 3.62 \\
\hline $\begin{array}{l}\text { Independence: The chance to work } \\
\text { alone on the job. }\end{array}$ & 3.49 & 3.8478 & 3.35 & 4 & 3.79 & 3.13 & 3.64 & 3.70 & 3.74 & 3.54 & 3.84 \\
\hline $\begin{array}{l}\text { Moral values: Being able to do } \\
\text { things that don't go against my } \\
\text { conscience }\end{array}$ & 3.38 & 3.6087 & 3.13 & $\begin{array}{c}3 \\
2 / 3\end{array}$ & 3.44 & 3.25 & 3.64 & 3.25 & 3.64 & 3.58 & 3.50 \\
\hline $\begin{array}{l}\text { Recognition: The praise I get from } \\
\text { doing a good job. }\end{array}$ & 3.26 & 3.1196 & 3.13 & 3 & 3.18 & 3.38 & 3.36 & 2.90 & 3.55 & 3.50 & 2.84 \\
\hline $\begin{array}{l}\text { Responsibility: The freedom to use } \\
\text { my own judgment. }\end{array}$ & 3.17 & 3.3370 & 3.13 & $\begin{array}{c}3 \\
1 / 3\end{array}$ & 3.38 & 2.63 & 3.00 & 3.00 & 3.40 & 3.29 & 3.30 \\
\hline $\begin{array}{l}\text { Security: The way my job provides } \\
\text { for steady employment. }\end{array}$ & 3.60 & 3.5761 & 3.39 & $\begin{array}{c}3 \\
6 / 7\end{array}$ & 3.41 & 3.38 & 3.00 & 3.25 & 3.60 & 3.71 & 3.70 \\
\hline $\begin{array}{l}\text { Social service: The chance to do } \\
\text { things for other people. }\end{array}$ & 3.70 & 3.8478 & 3.70 & $\begin{array}{c}3 \\
5 / 6\end{array}$ & 3.82 & 3.75 & 3.91 & 4.10 & 3.86 & 3.83 & 3.64 \\
\hline $\begin{array}{l}\text { Social status: The chance to be } \\
\text { "somebody" in the community. }\end{array}$ & 3.51 & 3.8696 & 3.52 & $\begin{array}{c}3 \\
5 / 6\end{array}$ & 3.94 & 3.00 & 3.64 & 4.05 & 3.62 & 3.46 & 3.84 \\
\hline $\begin{array}{l}\text { Supervision-human relations: The } \\
\text { way my boss handles his/her } \\
\text { workers. }\end{array}$ & 3.43 & 3.2935 & 3.22 & $\begin{array}{c}3 \\
1 / 3\end{array}$ & 3.41 & 3.13 & 3.00 & 3.20 & 3.74 & 3.38 & 3.04 \\
\hline $\begin{array}{l}\text { Supervision-technical: The } \\
\text { competence of my supervisor in } \\
\text { making decisions. }\end{array}$ & 3.15 & 3.1848 & 3.04 & $\begin{array}{c}3 \\
1 / 6\end{array}$ & 3.15 & 3.38 & 2.73 & 2.90 & 3.45 & 3.08 & 3.04 \\
\hline $\begin{array}{l}\text { Variety: The chance to do different } \\
\text { things from time to time. }\end{array}$ & 3.15 & 3.3043 & 2.96 & $\begin{array}{c}3 \\
1 / 3\end{array}$ & 3.12 & 3.38 & 3.27 & 3.15 & 3.38 & 3.08 & 3.24 \\
\hline Working conditions & 3.30 & 3.4891 & 3.13 & $\begin{array}{c}3 \\
4 / 9 \\
\end{array}$ & 3.56 & 3.38 & 3.09 & 3.10 & 3.48 & 3.54 & 3.46 \\
\hline Overall Score & 66.30 & 69.74 & 63.57 & 70 & 69.62 & 64.50 & 63.91 & 65.60 & 70.38 & 69.75 & 67.68 \\
\hline
\end{tabular}

Although descriptive statistic highlighted differences in the effect of respondents' characteristics on the level of their job satisfaction, it was important to identify which of these characteristics are statistically significant. To do so, forward regression analysis was performed and the result is reported in table (5). It is evident from the table that respondents' academic qualification was the least significant variable in determining the level of job satisfaction followed by work experience and academic rank. The status of the university whether public or private, the place where the last academic qualification was obtained, marital status and the age of the respondents appeared to be marginally significant determinants of job satisfaction. Yet, respondents' income, nationality and gender were statistically significant determinants of job satisfaction of academicians who work for business colleges in Kuwait.

\section{Conclusion}

The objective of this study is to identify the level of job satisfaction of academicians who work for business colleges in Kuwait. Kuwait currently has eight universities that offer business academic degrees. Some of these colleges offer two years Diploma, others offer Bachelor Degree and few MBA or MSc. To achieve the objective of the study, a commonly used short-form Minnesota Satisfaction Questionnaire (MSQ) to measure academicians job satisfaction was used. During the period between December 2016 and March 2017, 30 copies of the translated version of the questionnaire were distributed to academicians working in each of the eight Kuwaiti business colleges. 141 questionnaires returned completed, resulting in \%59 usable response rate. The result of the questionnaire analyses revealed that the respondents represent both Kuwaiti and non-Kuwaiti nationals. Some of them work for governmental business colleges and others work for private colleges. The respondents hold either Masters or PhD academic qualification. They obtained their last academic degrees from different countries, although graduates from USA and UK universities formed the majority. The respondents further occupying different academic ranks, representing both genders and vary in the years of work experience and income. Variations in the respondents' characteristics provide good grounds for comparison and credibility to the outcome of the study. The overall level of job satisfaction was relatively high $(68.42 \%)$. The respondents appeared to be highly satisfied with the social service and social status, independence, achievement and activity aspects of their jobs. They expressed moderate satisfaction with compensation, supervision, co-workers, authority and variety. The respondents, however, were less satisfied with the advancement, recognition, college policies and practices, supervision-technical, authority and variety aspect of job satisfaction. Although different characteristics of the respondents showed that they impact the level of their satisfaction as reflected by the resulted 
different means, regression analysis only pointed to three characteristics (income, nationality and gender) as statistically significant determinants job satisfaction of academicians work for business colleges in Kuwait.

Table (5). Backward Regression

\begin{tabular}{|c|c|c|c|c|c|c|c|c|c|c|c|c|c|c|}
\hline Model & $\mathrm{F}$ & Sig. & $\begin{array}{c}\text { Adj. } \\
\mathrm{R}^{2}\end{array}$ & $\beta_{0}$ & NAT & UNIV & GEN & MARS & ACCR & WORE & LANQ & AGE & PLAQ & INCO \\
\hline \multirow[t]{3}{*}{1} & .043 & 1.625 & .106 & -0.44 & 0.21 & -0.15 & 0.16 & 0.05 & -0.01 & 0.00 & 0.01 & 0.07 & -0.01 & 0.13 \\
\hline & & & & -1.097 & 1.848 & -1.106 & 1.685 & 0.476 & -0.121 & 0.066 & 0.053 & 1.014 & -0.162 & 1.967 \\
\hline & & & & $(0.275)$ & $(0.067)$ & $(0.271)$ & $(0.094)$ & $(0.635)$ & $(0.904)$ & $(0.947)$ & $(0.958)$ & $(0.312)$ & $(0.872)$ & $(0.051)$ \\
\hline \multirow[t]{3}{*}{2} & .050 & 1.819 & .070 & -0.44 & 0.21 & -0.15 & 0.16 & 0.05 & -0.01 & 0.00 & & 0.07 & -0.01 & 0.14 \\
\hline & & & & -1.10 & 1.86 & -1.11 & 1.70 & 0.49 & -0.11 & 0.06 & & 1.04 & -0.15 & 2.21 \\
\hline & & & & $(0.27)$ & $(0.07)$ & $(0.27)$ & $(0.09)$ & $(0.62)$ & $(0.91)$ & $(0.95)$ & & $(0.30)$ & $(0.88)$ & $(0.03)$ \\
\hline \multirow[t]{3}{*}{3} & .057 & 2.062 & .044 & -0.44 & 0.21 & -0.15 & 0.16 & 0.05 & 0.00 & & & 0.07 & -0.01 & 0.14 \\
\hline & & & & -1.11 & 1.87 & -1.13 & 1.71 & 0.49 & -0.10 & & & 1.26 & -0.15 & 2.22 \\
\hline & & & & $(0.27)$ & $(0.06)$ & $(0.26)$ & $(0.09)$ & $(0.62)$ & $(0.92)$ & & & $(0.21)$ & $(0.88)$ & $(0.03)$ \\
\hline \multirow[t]{3}{*}{4} & .064 & 2.373 & .026 & -0.43 & 0.21 & -0.15 & 0.16 & 0.05 & & & & 0.07 & 0.00 & 0.13 \\
\hline & & & & -1.11 & 1.90 & -1.13 & 1.71 & 0.49 & & & & 1.29 & -0.15 & 2.27 \\
\hline & & & & $(0.27)$ & $(0.06)$ & $(0.26)$ & $(0.09)$ & $(0.63)$ & & & & $(0.20)$ & $(0.89)$ & $(0.03)$ \\
\hline \multirow[t]{3}{*}{5} & .071 & 2.785 & .014 & -0.44 & 0.20 & -0.15 & 0.16 & 0.05 & & & & 0.07 & & 0.13 \\
\hline & & & & -1.16 & 1.91 & -1.12 & 1.73 & 0.47 & & & & 1.29 & & 2.28 \\
\hline & & & & $(0.25)$ & $(0.06)$ & $(0.26)$ & $(0.09)$ & $(0.64)$ & & & & $(0.20)$ & & $(0.02)$ \\
\hline \multirow[t]{3}{*}{6} & .076 & 3.316 & .007 & -0.43 & 0.21 & -0.14 & 0.18 & & & & & 0.07 & & 0.14 \\
\hline & & & & -1.15 & 1.97 & -1.06 & 1.94 & & & & & 1.33 & & 2.31 \\
\hline & & & & $(0.25)$ & $(0.05)$ & $(0.29)$ & $(0.06)$ & & & & & $(0.19)$ & & $(0.02)$ \\
\hline \multirow[t]{3}{*}{7} & .076 & 3.863 & .005 & -0.66 & 0.15 & & 0.18 & & & & & 0.08 & & 0.16 \\
\hline & & & & -2.11 & 1.66 & & 1.94 & & & & & 1.41 & & 3.10 \\
\hline & & & & $(0.04)$ & $(0.10)$ & & $(0.05)$ & & & & & $(0.16)$ & & $(0.00)$ \\
\hline \multirow[t]{3}{*}{8} & .069 & 4.452 & .005 & -0.43 & 0.16 & & 0.14 & & & & & & & 0.18 \\
\hline & & & & -1.60 & 1.74 & & 1.63 & & & & & & & 3.48 \\
\hline & & & & $(0.11)$ & $(0.08)$ & & $(0.11)$ & & & & & & & $(0.00)$ \\
\hline \multirow[t]{3}{*}{9} & .058 & 5.293 & .006 & -0.20 & 0.17 & & & & & & & & & 0.16 \\
\hline & & & & -0.89 & 1.88 & & & & & & & & & 3.18 \\
\hline & & & & $(0.38)$ & $(0.06)$ & & & & & & & & & $(0.00)$ \\
\hline
\end{tabular}

\section{Acknowledgement}

The authors wish to thank the Kuwait Foundation for the Advancement of Science (KFAS) for their financial support (project: P115-17IM-04).

\section{References}

Abushaira, M. (2012). Job satisfaction among special education teachers in Jordan. International Interdisciplinary Journal of Education, 1(3):48-56

Ahmad, W. and Abdurahman, S. (2015). Job satisfaction among academic staff of Universiti Utara Malaysia: A work environment perspective. Mediterranean Journal of Social Sciences, 6(3), 251-256. Doi:10.5901/mjss.2015.v6n3s2p251

Al-Abassi, A. (2004). Job satisfaction among Kuwaiti security officers. Journal of Social Sciences, 32(4), 867-899

Al-Aghbary, A. (2003). Job satisfaction of a simple of public school's principals at the Eastern Province Kingdom of Saudi Arabia. Journal of the Gulf and Arabian Peninsula Studies, 29(109), 69-177.

Al-Ahmadi, H. (2006). Job satisfaction and organizational commitment of primary healthcare professional in Saudi Arabia. Arab Journal of Administrative Sciences, 13(3), 305-332.

Al-Ajmi, R. (2001). The effect of personal characteristics on job satisfaction: A study among male managers in the Kuwait Oil Industry. International Journal of Commerce \& Management, 11(3/4), 91-110. http://dx.doi.org/10.1108/eb047429

Al-Madhon, M. \& Al-Baldani, A. (2005). Job satisfaction factors in academic private universities: Empirical study. AlEdari, 101(June), 53-79.

Al-Mashan, O. (1993). A comparative study of job satisfaction among employees of the public and private Sectors. Journal of Psychological Studies, 4(12), 569-595.

Al-Mashan, O. (1994). Effect of personal variables on the job satisfaction of Kuwaiti employees. Journal of Contemporary Psychological, 4(4), 73-103.

Al-Omar, B. (2003). Job dissatisfaction and nurse's withdrawal from Hospital in Riyadh City. Journal of King Saudi University, Administrative Sciences, 15(1), 1-24.

Al-Omar, F. (2000). Job dissatisfaction in Public Authorities in Kuwait. Al-Edari, 83 (December), 51-90.

Al-Rubaish, A.; Rahim, Sh.; Abumadini, M. \& Wisornu, L. (2009). Job Satisfaction among the academic staff of Saudi 
University: An evaluative study. Journal Family Community Med. 2009 Sep-Dec; 16(3), 97-103.

Bader, A. (1983). Job satisfaction: A comparative study between faculty members and administrators of College of Commerce, Economics and Political Sciences in University of Kuwait. Journal of Social Sciences, 11(3), 61-131.

Baldwin, T. (2009). Administrator job satisfaction in higher education (unpublished Ph.D. thesis). Auburn University.

Basak, S. (2014). A comparison of university academics job factors: Satisfaction and dissatisfaction. Journal of Economics and Behavioral Studies, 6(6), 500-508.

Bayram, N.; Gursakal, S. \& Bilgel, N. (2010). Burnout, vigor and job satisfaction among academic staff. European Journal of Social Sciences, 17(1), 41-53.

Bendern, K. \& Heywoodn, J. (2006). Job satisfaction of the highly educated: the role of gender, academic tenure and earnings. Scottish Journal of Political Economy, 53 (2), 253-279.

Buitendach, J. \& De Witte, D. (2005). Job insecurity, extrinsic and intrinsic job satisfaction and affective organizational commitment maintenance workers in a parastatal. South African Journal of Business Management, 36(2), 27-39.

Chimanikire, P., Mutandwa, E., Gadzirayi, C., Muzondo, N., \& Mutandwa, B. (2007). Factors affecting job satisfaction among academic professionals in tertiary institutions in Zimbabwe. African Journal of Business Management, $1(6), 166-175$.

Eyupoglu, S. \& Saner, T. (2009). Job satisfaction: Does rank make a difference?. African Journal of Business Management, 3(10), 609-615.

Khalid, S., Irshad, M., \& Mahmood, B. (2012). Job Satisfaction among academic staff: A comparative analysis between public and private sector universities of Punjab, Pakistan. International Journal of Business and Management, 7(1), 126-136. doi:10.5539/ijbm.v7n1p126

Leckie, G. \& Brett, J. (1997). Job satisfaction of Canadian university librarians: A national survey. College \& Research Libraries. 58(1), 31-47. Retrieved from http://crl.acrl.org/content/58/1/31.full.pdf

Leysen, J. \& Boydston, J. (2009). Job satisfaction among academic cataloger librarians, Collections and Technical Services Publications and Papers, 70(3), 273-297

Malik, N. (2011). A study on job satisfaction factors of faculty members at the University of Balochistan. Journal of Research in Education 21(2), 50-57

Mehmood, N.; Irum, S.; Ahmed, K. \& Sultana, A. (2012). A study of factors affecting job satisfaction (Evidence from Pakistan). Interdisciplinary Journal of Contemporary Research Business, 4(6), 273-284

Mehrad, A.; Hamsan, H.; Redzuan, M. \& Abdullah, H. (2015). The role of job satisfaction among academic staff at university. Proceeding of the $3^{\text {rd }}$ Global Summit on Education GSE 2015 (e-ISBN 978-967-0792-01-1), 9-10 March 2015, Kuala Lumpur, MALAYSIA. Organized by http://WorldConferences.net pp 572-577.

Mustapha, N. (2013). The influence of financial reward on job satisfaction among academic staffs at public universities in Kelantan, Malaysia. International Journal of Business and Social Science, 4(3), 244-248

Noordin, F. \& Jusoff, K. (2009). Levels of job satisfaction amongst Malaysian academic staff. Asian Social Sciences, 5(5), 122-128. http://dx.doi.org/10.5539/ass.v5n5p122

Oshagbemi T. (1996). Job satisfaction of UK academicians. Educational Management \& Administration, 24(4), 389-400.

Oshagbemi, T. (2000). Gender differences in the job satisfaction of university teachers. Women in Management Review, 15(7), 331-343. https://doi.org/10.1108/09649420010378133

Oshagbemi, T. (2003). Personal correlates of job satisfaction: empirical evidence from UK universities. International Journal of Social Economics, 30(12), 1210-1231. DOI 10.1108/03068290310500634

Robbins, S.; Odendaal, A. \& Roodt, G. (2003). Organizational behavior: global and South African perspectives. Cape Town: Pearson Education.

Saba, I. (2011). Measuring the job satisfaction level of the academic staff in Bahawalpur colleges. International Journal of Academic Research in Business and Social Sciences, 1(1). http://www.hrmars.com/admin/pics/18.pdf

Saif, S., Nawaz, A., Jan, F. \& Khan, M. (2012). Synthesizing the theories of job-satisfaction across the cultural/attitudinal dimensions. Interdisciplinary Journal of Contemporary Research Business, 3(9), 1382-1396.

Santhapparaj, A. \& Alam, S. (2005). Job satisfaction among academic staff in private universities in Malaysia. Journal of Social Sciences, 1(2), 72-76.

Saygi, H., Tolon, T., \& Tekogul, H. (2011). Job satisfaction among academic staff in Fisheries faculties at Turkish universities. Social Behaviour and Personality, 39(10), 1395-1402. https://doi.org/10.2224/sbp.2011.39.10.1395

Schulze, S. (2006). Factors influencing the job satisfaction of academicians in higher education. South African Journal of Higher Education, 20(2), 318-335. 
Shamra, Sh. \& Manani, P. (2012). Job satisfaction: An arising urge to put theory into practice. South Asian Academic Research Journal, 2(1), 66-73.

Shin, J. \& Jung, J. (2014). Academics job satisfaction and job stress across countries in the changing academic environments. Higher Education, 67(5), 603-620.

Sohail, M. \& Delin, H. (2013). Job satisfaction surrounded by academics staff: a case study of job satisfaction of academics staff of the GCUL, Pakistan. Interdisciplinary Journal of Contemporary Research in Business, 4(11), 126-137.

Sseganga, K. (2003). Job Satisfaction and Dissatisfaction of University Academicians: Perspectives from Uganda. Uganda Journal of Education, 4(July - December), 65-89.

Ssesanga, K., \& Garrett, R. (2005). Job satisfaction of university academicians: Perspectives from Uganda. Higher Education, 50(1), 33-56. http://dx.doi.org/10.1007/s10734-004-6346-0

Stevens, Ph. (2005). The job satisfaction of English academicians and their intentions to quit academe, NIESR Discussion Papers 262, National Institute of Economic and Social Research.

Steyn, G. \& Van, J. (1999). Job Satisfaction: perception of principals and teachers in urban black schools in South Africa. South African Journal of Education, 19(1), 37-43.

Syed, A. \& Ahmedani, M. (2013).Comparative analysis of job satisfaction among Faculty members of Shah Abdul Latif University Khairpur Mirs compare with University of Sindh Jamshoro. Journal of Business Strategies, 7(2), 9-18.

Teck-Hong, T. \& Waheed, A. (2011). Herzberg's motivation-hygiene theory and job satisfaction in the Malaysian retail sector: The mediating effect of love of money. Asian Academy of Management Journal, 16 (1), 73-94

Toker, B. (2011). Job satisfaction of academic staff: an empirical study on Turkey. Quality Assurance in Education, 19(2), 156-169. https://doi.org/10.1108/09684881111125050

Wang, Ch., Nguyen, N. \& Tuyen, T. (2014). The study of staff satisfaction in consulting center system- A case study of job consulting centers in Ho Chi Minh City, Vietnam. Asian Economic and Financial Review, 4(4), 472-491.

Ward, M. \& Sloane, P. (2000). Job satisfaction within the Scottish academic profession. Scottish Journal of Political Economy, 47(3), 273-303.

Weiss, D.; Daws, R.; England, G. \& Lofquist, L. (1967). Minnesota job satisfaction questionnaire, manual for Minnesota, satisfaction questionnaire, industrial relations centers, University of Minnesota.

Zarafshani, K. \& Alibaygi, A. (2008). Predictors of job satisfaction among academicians in Iranian University. http://www.nactateachers.org/attachments/article/178/Kiumars_NACTA_Journal_December_2008.pdf

Zayed, K. (2008). Omani physical educators' job satisfaction and its relationship with selected variables. Journal of educational and Psychological Sciences, 9(4), 161-182. Available at: http://search.shamaa.org/PDF/Articles/BAJepsc/8JepscVol9No4Y2008/7JepscVo19No4Y2008.pdf

\section{Copyrights}

Copyright for this article is retained by the author(s), with first publication rights granted to the journal.

This is an open-access article distributed under the terms and conditions of the Creative Commons Attribution license (http://creativecommons.org/licenses/by/4.0/). 